\title{
Obtaining conductive composites of PANI and thermoplastic polymers
}

\section{Obtención de compositos conductores de PANI y polímeros termoplásticos}

\author{
CONTRERAS-ZARAZÚA, Diana Nelly†, CONTRERAS-LOPÉZ, David*, FUENTES-RAMIREZ, \\ Rosalba and GALINDO-GONZÁLEZ Rosario
}

Universidad de Guanajuato

ID $1^{\text {st }}$ Author: Diana Nelly, Contreras-Zarazúa / ORC ID: 0000-0001-8398-0865, CVU CONACYT ID: 885541

ID $1^{\text {st }}$ Coauthor: David, Contreras-Lopéz / ORC ID: 0000-0003-1384-4766, CVU CONACYT ID: 38297

ID $2^{\text {nd }}$ Coauthor: Rosalba, Fuentes-Ramirez / ORC ID: 0000-0003-0520-3387, CVU CONACYT ID: 202669

ID $3^{\text {rd }}$ Coauthor: Rosario, Galindo-González / ORC ID: 0000-0002-3612-1555, CVU CONACYT ID: 223987

DOI: $10.35429 / J Q S A .2019 .18 .6 .11 .15$

Received January 26, 2019; Accepted April 03, 2019

\begin{abstract}
Currently, the polymers industry has gained increasing importance due to the versatility of its properties. In this work were synthesized copolymers of styrene with vinyl acetate at different concentrations through a process polymerization of suspension, which are the starting points for obtaining of composites with polyaniline synthesized PANI chemical oxidative polymerization process, used for doping $\mathrm{HCl}$ at a concentration of $1.5 \mathrm{M}$ and ammonium persulfate $0.5 \mathrm{M}$ in a mass radio of $1: 1$. The conductivity was evaluated by means of cyclic voltammetry and impedance spectroscopy, in order to determine the effect of the concentration of the polar monomer in the composite founded that increase concentration of polar comonomer the conductivity also too.
\end{abstract}

Conductive polymers, Copolymers, Polyaniline

\begin{abstract}
Resumen
En la actualidad, la industria de los polímeros ha cobrado una creciente importancia debido a la versatilidad de sus propiedades. En el presente trabajo de investigación, se sintetizaron copolímeros de estireno con acetato de vinilo a diferentes concentraciones en peso con respecto al estireno, mediante un proceso de polimerización por suspensión, los cuales son los puntos de partida para obtención de compositos conductores de polianilina (PANI). El PANI se sintetizo mediante un proceso de de química oxidativa, empleado para ello, un dopaje de $\mathrm{HCl}$ a una concentración de $1.5 \mathrm{M}$ y persulfato de amonio 0.5 $\mathrm{M}$ en una relación másica de 1:1. Se evaluó la conductividad por medio de voltamperometría cíclica y espectroscopia de impedancia, con el objeto de determinar el efecto de la concentración del comonómero polar en el composito, encontrándose una que conforme aumenta la concentración del comonómero polar, la conductividad se incrementa.
\end{abstract}

Polímeros conductores, Copolímeros, Polianilina

Citación: CONTRERAS-ZARAZÚA, Diana Nelly, CONTRERAS-LOPÉZ, David, FUENTES-RAMIREZ, Rosalba and GALINDO-GONZÁLEZ Rosario. Obtaining conductive composites of PANI and thermoplastic polymers. Journal of Quantitative and Statistical Analysis. 2019 6-18: 11-15

\footnotetext{
* Correspondence to Author (email: david.contreras@ugto.mx)

$\dagger$ Investigador contribuyendo como primer autor.
} 


\section{Introduction}

During recent years, the chemical industry focused on the development of polymeric materials has been increasing, demanding new materials with specific characteristics, due to this, conductive polymers are a growing area. These materials present a low cost of production, and a great variety of applications, for example, if they are used in solar or fuel cells, even being substitutes for some metals, which to obtain a large number of polluting processes and higher costs. This has given guidelines to review the effect that the products consumed have on the care of the environment.

The synthesis of vinyl-type copolymers is proceeded by a conventional polymerization mechanism free radical addition (FRP) by the suspension process. This method of production, industrially is the most common industrial level, mainly for the production of plastics, rubber and fibers; in comparison with other polymerization processes, since it has the advantage of being applied to a large variety of vinyl type monomers, it is easy to implement experimentally and is a relatively easy process to control, giving polymers with predetermined molecular weights by ratio of monomer concentrations consumed. [1]

\section{Conductive polymers}

This type of polymers also called synthetic metals or organic metals, were discovered in the decade of the 70's and since then until today a great interest has been awakened in the industrial and academic area. It should be noted that most organic polymers are excellent electrical insulators; while conducting polymers are capable of conducting electric current, being synthetic and almost all organic. These have delocalized links (often with an aromatic group) that form a structure similar to that of silicon. The most common conductive polymers are polypyrrole, polythiophene and polyaniline.

\section{Polyaniline}

Polyaniline (PANI) is a product of the oxidation of its monomer (aniline) in acidic conditions and is presented in 4 stable forms, depending on its level of oxidation: base pernigranilina (totally oxidized), emerald (partially oxidized) and leucoesmeraldina (totally reduced). Of these, the emerald base is the most stable and conductive. [2]
The PANI can be mixed with different types of polymers, providing conductivity to the resulting material, and accepting the properties of mechanical strength and / or processability left by the emitting polymer matrix. The production of a new class of materials by mixing polyaniline, ensures that a conductive material is dispersed in an insulating matrix, thin films are obtained by chemical or electrochemical synthesis in situ. The main dopants for the synthesis of aniline are hydrochloric acid $(\mathrm{HCl})$, sulfuric acid $\left(\mathrm{H}_{2} \mathrm{SO}_{4}\right)$, camphorsulfonic acid, acid phosphate ester and acetic acid. [3]

\section{Materials and methods}

\section{Synthesis of copolymers}

The synthesis of the copolymers was carried out with the monomers styrene (S) and vinyl acetate (VAc) at different percentages by weight with respect to styrene, and was obtained by means of a suspension polymerization process via conventional free radicals (FRP). Previously, the monomers are washed to remove the inhibitor, using $0.1 \mathrm{M}$ sodium hydroxide (three times) and two with distilled water. Styrene and vinyl acetate used, have purity percentage> 99\% (Sigma-Aldrich).

Continuing with the suspension polymerization process, this is carried out in a $250 \mathrm{~mL}$ reactor, using as a continuous medium an aqueous solution of PVA $89000 \mathrm{Da}, 88 \%$ hydrolyzed ( $5 \mathrm{~g} / \mathrm{L})$. While, for the dispersed phase, the S-VAc mixture is added at $1 \%, 5 \%$, $10 \%, 15 \%, 20 \%$ and $25 \%$ by weight, as the case may be, based on $20 \mathrm{~mL}$ of styrene. Benzoyl peroxide (BPO) reagent grade (Sigma-Aldrich) was used as the initiator.benzoilo), calculating the necessary weight for each mixture.

The synthesis was carried out at $85 \pm 2^{\circ}$ $\mathrm{C}$ at $400 \mathrm{rpm}$, in approximately 3 hours. When the copolymer is obtained, it is cooled in an ice bath and purified, filtering by gravity and washing with distilled water and $99.8 \%$ pure methanol, finally the yield and molecular weights are calculated. For the determination of molecular weights by viscosity (Mv) a CannonFenske \# 25 viscometer and the Mark-Houwink equation were used, using the values of the constants presented in Table 1. 


\begin{tabular}{|c|c|c|}
\hline Copolymer & $\alpha$ & $\mathrm{K}$ \\
\hline S-VAc 1\% & 0.6191 & 0.03771 \\
\hline S-VAc 5\% & 0.6155 & 0.04055 \\
\hline S-VAc 10 & 0.611 & 0.0441 \\
\hline S - VAc $15 \%$ & 0.6065 & 0.04765 \\
\hline S - VAc $20 \%$ & 0.602 & 0.0512 \\
\hline S - VAc $25 \%$ & 0.5975 & 0.05475 \\
\hline
\end{tabular}

Table 1 Mark-Houwink constants

\section{Synthesis of Polyaniline}

This reaction was carried out using the high purity aniline monomer (ANI, Sigma-Aldrich), $0.5 \mathrm{M}$ ammonium persulphate solution and 1.5 M solution of hydrochloric acid ( $\mathrm{HCl}$ ) as doping agent, in a $250 \mathrm{~mL}$ reactor. Polymerization of oxidative chemistry started by adding $2.59 \mathrm{~g}$ of aniline to the reactor where previously $50 \mathrm{~mL}$ of $1.5 \mathrm{M} \mathrm{HCl}$ had been added, allowing the aniline to react for $25 \mathrm{~min}$ at $800 \mathrm{rpm}$, after this time, 50 $\mathrm{mL}$ of $0.5 \mathrm{M}$ ammonium persulphate solution is added, leaving the reaction for 3 hours. Concluding this step, it is filtered by and washed with distilled water and methanol, subsequently, it is dried at $45^{\circ} \mathrm{C}$ for a period of approximately 24 hours until a constant weight of the conductive polymer is obtained.

\section{Obtaining composites}

To obtain the composites at different percentages, mixtures were elaborated in relation to the 1: 1 weight of the PANI as the conducting polymer at a degree of doping (1.5 $\mathrm{M})$ and of the copolymer at different percentages by weight of vinyl acetate $(1 \%, 5 \%, 10 \%, 15 \%$, $20 \%$ and $25 \%$ ). Mixing mechanically, adding on a watch glass $0.1 \mathrm{~g}$ of PANI and $0.1 \mathrm{~g}$ of the selected copolymer, adding 200 microliters of toluene to homogenize and a sonicator was used for 5 minutes to unify the mixture. Subsequently, the samples were placed in FTO glasses in an area of $1 \mathrm{~cm} 2$ and allowed to dry. Having the final composites, they were characterized by cyclic voltammetry and impedance spectroscopy to determine the conductivity of the polymer.

\section{Results and discussion}

Obtaining the S-VAc copolymers by the suspension polymerization method was relatively simple, having a precise control of the temperature and reaction time, there were no problems, in the same way, in the process of separation and purification of the compound.
Following the methodology outlined above, copolymers were obtained at different percentages of vinyl acetate with respect to styrene. In the product obtained, the change in particle size is notable and its homogeneity decreases as the percentage of VAc present increases, It also shows a large amount of coalescence and pearl breaks, this can be seen in Figure 1.

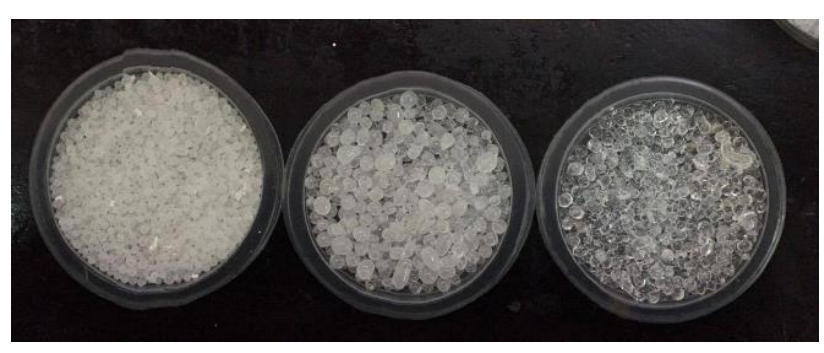

Figure 1 Pearls obtained from S - VAc at 15\%, 20\% and $25 \% \mathrm{w} / \mathrm{S}$

Molecular weight tests of the composites were performed using the capillary viscometry technique, preparing $10 \mathrm{~mL}$ solutions, with concentrations of $0.01 \mathrm{~g} / \mathrm{mL}, 0.005 \mathrm{~g} / \mathrm{L}$ and $0.001 \mathrm{~g} / \mathrm{L}$ using toluene> $99 \%$ as solvent medium. From each solution, $7 \mathrm{~mL}$ was used to analyze and each test was done in triplicate.

In Table 2 the molecular weights $(\mathrm{Mw})$ obtained by this technique can be observed for the copolymers of S-VAc at $1 \%, 5 \%, 10 \%, 15 \%$, $20 \%$ and $25 \%$ by weight with respect to styrene. The yields of each of the copolymerization reactions are also observed, by the wet weight and dry weight of the resulting product.

\begin{tabular}{|l|r|r|}
\multicolumn{1}{|c}{ Material } & \multicolumn{1}{c}{$\begin{array}{c}\text { Performance } \\
(\%)\end{array}$} & \multicolumn{1}{c|}{$\begin{array}{c}\text { Molecular weight } \\
\text { Mw (g/mol) }\end{array}$} \\
\hline S -VAc 1\% & 85.28 & $12,671.67$ \\
\hline S-VAc 5\% & 90.86 & $151,111.97$ \\
\hline S - VAc 10 & 89.03 & $157,455.56$ \\
\hline S - VAc 15 \% & 92.5 & $27,264.5016$ \\
\hline S - VAc 20 \% & 81.63 & $26,992.8684$ \\
\hline S - VAc 25\% & 72.6 & $81,073.14$ \\
\hline
\end{tabular}

Table 2 Yields and molecular weights of S-VAc copolymers

In the case of performance, a small range of variation is noted, however, in the calculated molecular weights, an increase considered in percentages of $5 \%$ and $10 \%$ is clear, having values without a visible tendency. 


\section{Cyclic voltaperometry and impedance spectroscopy}

According to what was formulated in the methodology, electrochemical tests of cyclic voltammetry and impedance spectroscopy were performed on the PANI synthesized, demonstrating the conductive characteristics present in this polymer.

Previously, the characteristic color of this compound, emerald green, which shows the partially oxidized state of polyaniline, had been revised.

The voltaperometric analysis was carried out in a potentiostat model SSP-150 Biologic Science Instruments with Software Ec-Lab V10.19, and a three-electrode cell at room temperature, using a working carbon electrode of $0.001 \mathrm{~cm} 2$, with previous polishing with alumina powder $0.03,0$. and $0.5 \mu \mathrm{m}$, then sonicate for $3 \mathrm{~min}$ and wash with deionized water, was used an electrode type Ag / AgNO3, and a platinum wire electrode with spring arrangement.

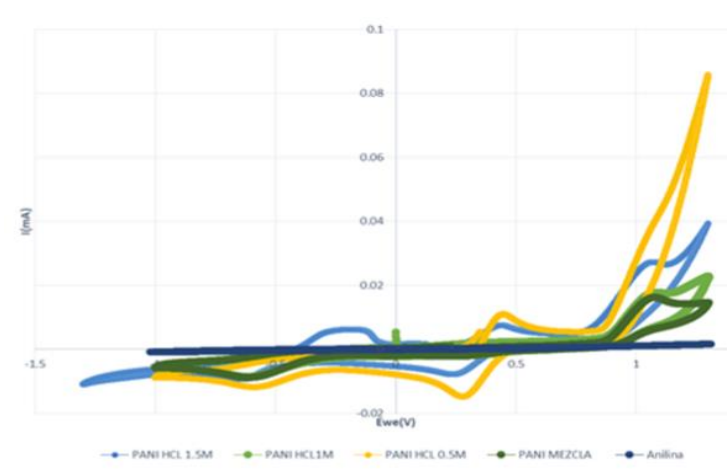

Figure 2 PANI voltammetry as well as the aniline monomer.

In Figure 2, the PANI voltaperogram is shown at different concentrations of doping agent, noting that the concentration of $1.5 \mathrm{M} \mathrm{HCl}$ increases the conductive character, with respect to the behavior of these voltammograms, it can also be identified that the aniline spectrum has no conductive property.

In the quantitative analysis of the conductivity of the PANI at different concentrations of doping agent were performed with the impedance spectroscopy technique, the spectrum is shown in Figure 3.

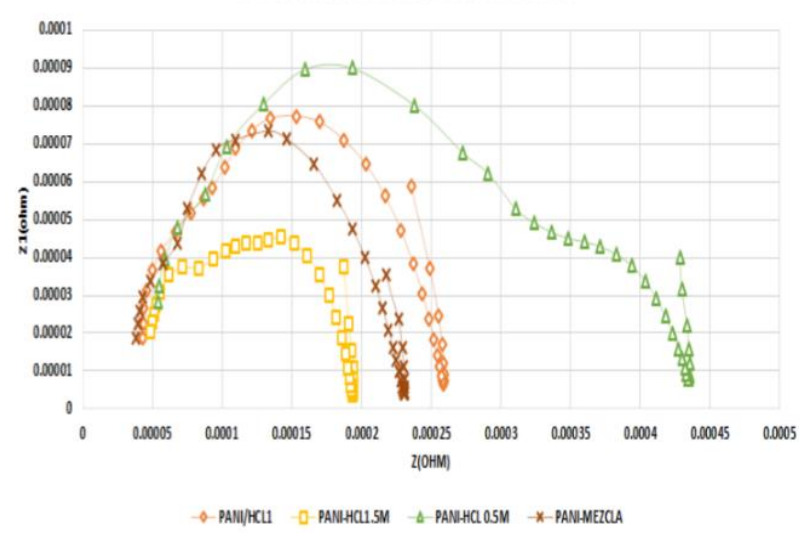

Figure 3 PANI impedance spectroscopy at different concentrations of $\mathrm{HCl}$

As can be seen in the previous spectrum, the higher concentration of doping agent decreases the resistance of the material. With these resistances, the resistivities of the material and their respective conductivities can be obtained (see Table 3).

\begin{tabular}{|l|c|c|c|}
\hline \multicolumn{1}{|c|}{ Material } & $\begin{array}{c}\text { Resistance } \\
(\Omega)\end{array}$ & $\begin{array}{c}\text { Resistivity } \\
\left(\Omega^{-1}\right)\end{array}$ & $\begin{array}{c}\text { Conductivity } \\
(\mathrm{S} / \mathrm{cm})\end{array}$ \\
\hline $\begin{array}{l}\mathrm{PANI} / \mathrm{HCl} \\
0.5 \mathrm{M}\end{array}$ & $3.4 \times 10^{-4}$ & $1.21 \times 10^{-2}$ & 82.43 \\
\hline $\begin{array}{l}\mathrm{PANI} / \mathrm{HCl} \\
1.0 \mathrm{M}\end{array}$ & $2 \times 10^{-4}$ & $7.14 \times 10^{-3}$ & 140.14 \\
\hline $\begin{array}{l}\mathrm{PANI} / \mathrm{HCl} \\
1.5 \mathrm{M}\end{array}$ & $1.35 \times 10^{-4}$ & $4.781 \times 10^{-2}$ & 209.16 \\
\hline
\end{tabular}

Table 3. PANI conductivity table

In the previous table, it is noted that increasing the concentration of the doping agent improves the conductive properties of the polymeric material, considering it a semiconductor, with a maximum conductivity of $209.16 \mathrm{~S} / \mathrm{cm}$.

For the analysis of impedance spectroscopy of the composites, it was carried out in the FTO glasses, which are applied to measure their conductive capacity.

These materials were worked in $10 \mathrm{ml}$ of potassium chloride support electrolyte $0.1 \mathrm{M}$, and with an impregnation area in the working electrode of $1 \mathrm{~cm} 2$.

With the spectra, the resistivities and conductivities of the 6 composites presented above were calculated. 


\begin{tabular}{|c|c|c|c|}
\hline Material & $\begin{array}{l}\text { Resistance } \\
(\Omega)\end{array}$ & $\begin{array}{l}\text { Resistivity } \\
\qquad\left(\Omega^{-1}\right)\end{array}$ & $\begin{array}{l}\text { Conductivity } \\
(\mathrm{S} / \mathrm{cm})\end{array}$ \\
\hline $\begin{array}{ll}\mathrm{S} & -\mathrm{VAc} \\
1 \% & \end{array}$ & $9.98 \times 10^{-3}$ & $4.96 \times 10^{-3}$ & 201.6 \\
\hline $\begin{array}{l}S-V A c \\
5 \%\end{array}$ & $3.89 \times 10^{-3}$ & $1.94 \times 10^{-3}$ & 515.5 \\
\hline $\begin{array}{l}S-V A c \\
10\end{array}$ & $3.24 \times 10^{-3}$ & $1.66 \times 10^{-3}$ & 601.7 \\
\hline $\begin{array}{l}\mathrm{S}-\mathrm{VAc} \\
15 \%\end{array}$ & $2.25 \times 10^{-3}$ & $1.38 \times 10^{-3}$ & 724.58 \\
\hline $\begin{array}{l}\mathrm{S}-\mathrm{VAc} \\
20 \%\end{array}$ & $1.06 \times 10^{-3}$ & $1.27 \times 10^{-3}$ & 786.34 \\
\hline $\begin{array}{l}\mathrm{S}-\mathrm{VAc} \\
25 \%\end{array}$ & $8.15 \times 10^{-4}$ & $1.13 \times 10^{-3}$ & 886.32 \\
\hline
\end{tabular}

Table 4 Table of conductivities of the composites with aniline at $1.5 \mathrm{M}$.

In Table 4, the conductivities tendency for composites is shown, where it can be observed that by increasing the concentration of the polar comonomer, the conductivity of the material increases. We can attribute these results to the chemical conformation of the S-VAc copolymer, where the vinyl acetate molecule presents its carbonyl group below the main chain, causing the carbonyl to provide a good mobility of electrons, consequently, a greater conduction, in comparison to a composition of $\mathrm{S}$ - methyl methacrylate (MMA) (Presented in the article "Synthesis of phenyl-type conducting polymers") [5], as the concentration of MMA increases, its conductive capacity decreases, the application of VAc in conductive materials is more feasible.

\section{Conclusions}

The S-VAc copolymers were synthesized successfully at different percentages by weight, obtaining good yields for this experimental part. It is worth mentioning that it was used as a conductive polymer PANI at a concentration of doping agent of $1.5 \mathrm{M}$, demonstrating a good conductive property.

In prepared composites, it is noted that by increasing the percentage polar monomer (VAc), increases the conductivity proportionally in these matrices.

\section{References}

[1] Coessens, V., Pintauer, T., y Matyjaszewski, K. (2001). Functional polymers by atom transfer radical polymerization
[2] Balint, R., Cassidy, N. and Cartmell, S. (2014). Conductive polymers: Towards a smart biomaterial for tissue engineering. Acta Biomaterialia,10(6), pp.2341-2353. Doi: 10.1016/j.actbio.2014.02.015

[3] Rodriguez P. J. Josue. (2016). Polimerización en suspensión de copolímeros de estireno por radicales libres para la formación de compositos de Polianilina. Jovenes en la Ciencia 2017, 3, 245

[4] Gacén, Cayuela D. y Galizia M. (2000). Peso molecular de las fibras acrílicas.

[5] F. Fernando, Galindo M. Contreras D. (2017). Síntesis de polímeros conductors tipo fenílicos. Verano de Investigacion UG 2017 